\title{
Paclitaxel increases the sensitivity of lung cancer cells to lobaplatin via PI3K/Akt pathway
}

\author{
DONGJIE MA, SHANQING LI, YUSHANG CUI, LI LI, HONGSHENG LIU, YEYE CHEN and XIAOYUN ZHOU
}

\author{
Department of Thoracic Surgery, Peking Union Medical College Hospital, Peking Union Medical College \\ and Chinese Academy of Medical Sciences, Beijing 100730, P.R. China
}

Received August 22, 2017; Accepted January 9, 2018

DOI: $10.3892 / \mathrm{ol} .2018 .8086$

\begin{abstract}
The effect of paclitaxel combined with lobaplatin on the sensitivity of lung cancer cell line NCI-H446 through influencing the phosphatidylinositol 3-kinase (PI3K)/Akt pathway was investigated. The sensitivity of lobaplatin to NCI-H446 and the effect of paclitaxel and PI3K inhibitor LY294002 combined with lobaplatin on the sensitivity to NCI-H446 were detected via methyl thiazolyltetrazolium (MTT) assay. The effect of paclitaxel combined with lobaplatin on cell apoptosis was detected using flow cytometry, the effect of paclitaxel combined with lobaplatin on the cell migration was detected via cell wound scratch assay, and the effect of paclitaxel combined with lobaplatin on the cell invasion was detected via Transwell assay. Finally, the effect of paclitaxel on PI3K/Akt pathway was detected via western blotting. MTT assay showed that $30 \mu \mathrm{g} / \mathrm{ml}$ lobaplatin could significantly inhibit the growth of NCI-H446 $(\mathrm{p}<0.01)$. Lobaplatin group (group L), $2 \mu \mathrm{g} / \mathrm{ml}$ paclitaxel combined with lobaplatin group (group LP) and lobaplatin combined with $10 \mu \mathrm{mol} / \mathrm{ml}$ LY294002 group (group LL) were set up. The cell survival rates in group LP and group LL were significantly lower than that in group $L(p<0.01)$, and the cell survival rate in group LP was similar to that in group LL $(\mathrm{p}>0.05)$. Flow cytometry revealed that the cell apoptotic levels in group LP and group LL were obviously higher than that in group $\mathrm{L}(\mathrm{p}<0.01)$, and there was no statistically significant difference in the cell apoptotic level between group LP and group LL $(p>0.05)$. Cell wound scratch assay showed that the cell migration capacity in group LP was significantly lower than those in group L and group LL $(\mathrm{p}<0.01, \mathrm{p}<0.05)$, and the cell migration capacity in group LL was lower than that in group $\mathrm{L}(\mathrm{p}<0.05)$. Besides, Transwell assay revealed that the cell invasion capacity in group LP was obviously
\end{abstract}

Correspondence to: Dr Shanqing Li, Department of Thoracic Surgery, Peking Union Medical College Hospital, Peking Union Medical College and Chinese Academy of Medical Sciences, 1 Shuai Fuyuan Street, Dong Cheng, Beijing 100730, P.R. China

E-mail: liannezhongzi@163.com

Key words: paclitaxel, lobaplatin, PI3K/Akt, lung cancer lower than those in group L and group LL $(\mathrm{p}<0.01, \mathrm{p}<0.05)$, and the cell invasion capacity in group LL was lower than that in group $\mathrm{L}(\mathrm{p}<0.01)$. Finally, western blotting showed that the levels of PI3K, phosphorylated-Akt (p-Akt) and phosphorylated-glycogen synthase kinase $3 \beta$ (p-GSK $3 \beta$ ) in group LP and group LL were significantly lower than those in group L, and the differences were statistically significant $(\mathrm{p}<0.01)$. Paclitaxel can significantly increase the sensitivity of lobaplatin to lung cancer cell line NCI-H446. Moreover, paclitaxel can enhance the effect of lobaplatin on lung cancer cells and reduce the drug resistance through inhibiting PI3K/Akt pathway.

\section{Introduction}

Lung cancer is caused by the interaction among smoking, environmental and genetic factors and is currently the most clinically common respiratory system tumor, and it is the shortened form of primary bronchogenic carcinoma (1). Lung cancer has a high mortality rate, and the 5-year survival rate of lung cancer patients is $<20 \%$. Surgery is currently the major treatment means of lung cancer, and the clinical treatment of this disease is unsatisfactory at present, mainly because lung cancer is prone to spread, and the patients have often missed the best opportunity of surgical resection when diagnosed (2,3). Patients lacking the surgical conditions are often treated with the combined therapy of chemotherapy and radiotherapy. The commonly-used chemotherapy methods are the platinum drugs combined with cytotoxic drugs, such as lobaplatin combined with gemcitabine used for the treatment of lung cancer $(4,5)$. Platinum drugs have a strong effect of killing lung cancer cells, but lung cancer cells will produce resistance to platinum drugs, resulting in decreased sensitivity of lung cancer cells and finally loss of the therapeutic effect (6). Paclitaxel is a kind of antitumor drug that acts on tubulin, and its effective rate in the treatment of lung cancer is $<15 \%$. Ueno and Mamounas (7) found that paclitaxel can increase the sensitivity of carboplatin to breast cancer, enhance the effect of carboplatin and effectively prolong the survival time of breast cancer patients. Zou et al (8) found that paclitaxel can effectively reduce the migration and invasion capacities of colon cancer cells, and inhibit the proliferation of colon cancer cells through reducing the expression level of phosphorylated-Akt (p-Akt). A large number of studies 
have shown that phosphatidylinositol 3-kinase (PI3K)/Akt is involved in the proliferation process of multiple tumors, and a variety of antitumor drugs can play an antitumor role through acting on the PI3K/Akt signaling pathway $(9,10)$.

In the present study, the sensitivity of cancer cells to lobaplatin in the treatment of lung cancer cells with paclitaxel combined with lobaplatin, and whether PI3K/Akt signaling pathway was involved in the effect of paclitaxel on lung cancer cells was investigated, so as to provide a theoretical basis for the clinical treatment of lung cancer with paclitaxel combined with lobaplatin.

\section{Materials and methods}

Reagents and instruments. Lung cancer cell line NCI-H446 (Kunming Cell Bank, Chinese Academy of Sciences); methyl thiazolyltetrazolium (MTT), dimethylsulfoxide (DMSO), paclitaxel, lobaplatin and LY294002 (Sigma, St. Louis, MO, USA); RPMI-1640 medium (Gibco; Thermo Fisher Scientific, Inc., Waltham, MA, USA); rabbit anti-human PI3K, p-Akt, AKT, phosphorylated-glycogen synthase kinase $3 \beta$ (p-GSK3 $\beta$ ), GSK3 $\beta, \beta$-actin monoclonal antibody and goat anti-rabbit secondary polyclonal antibody (cat. nos. 4249, 4060, 4685, 9323, 9315, 4970 and 14708) (Cell Signaling Technology, Danvers, MA, USA); Annexin V-FITC apoptosis assay kit (BD Biosciences, Heidelberg, Germany); inverted fluorescence microscope (Thermo Fisher Scientific, Inc., Waltham, MA, USA); cell culture bottle (Corning Inc., Corning, NY, USA); Transwell chamber (EMD Millipore, Billerica, MA, USA) and pipettor (Eppendorf AG, Hamburg, Germany).

Detection of cell survival rate. The lung cancer cell line NCI-H446 purchased from Kunmíng Cell Bank, Chinese Academy of Sciences were cultured at $37^{\circ} \mathrm{C}$ and $5 \% \mathrm{CO}_{2}$ after the replacement of medium, followed by passage at $80 \%$ cell confluency. The cells continued to be cultured until the logarithmic phase for the experiments. After cells were placed in the 96-well plate overnight, lobaplatin in different concentrations $(5,10,20,30,50$ and $80 \mu \mathrm{g} / \mathrm{ml})$ was added for incubation at $37^{\circ} \mathrm{C}$ and $5 \% \mathrm{CO}_{2}$ for $24 \mathrm{~h}$. Then MTT was added for incubation for $4 \mathrm{~h}$. The culture solution was adsorbed and DMSO was added, followed by detection of absorbance value using the microplate reader and calculation of cell survival rate. Lobaplatin in appropriate concentration was selected and added into the cells based on the time gradient for incubation for $6,12,24$ and $48 \mathrm{~h}$, respectively. The effects of different treatment time on cell survival rates were detected via MTT assay. According to the above experimental results, lobaplatin group (group L), $2 \mu \mathrm{g} / \mathrm{ml}$ paclitaxel combined with lobaplatin group (group LP) and lobaplatin combined with $10 \mu \mathrm{mol} / \mathrm{ml}$ LY294002 group (group LL) were set up. The cell survival rate in each group was detected via MTT assay after incubation for $24 \mathrm{~h}$.

Detection of cell apoptosis. The density of cells in the logarithmic growth phase was adjusted to $1 \times 10^{6}$ cells $/ \mathrm{ml}$ and spread evenly on the 6-well plate. Group L, group LP and group LL were set up. At $2 \mathrm{~h}$ before lobaplatin was added,

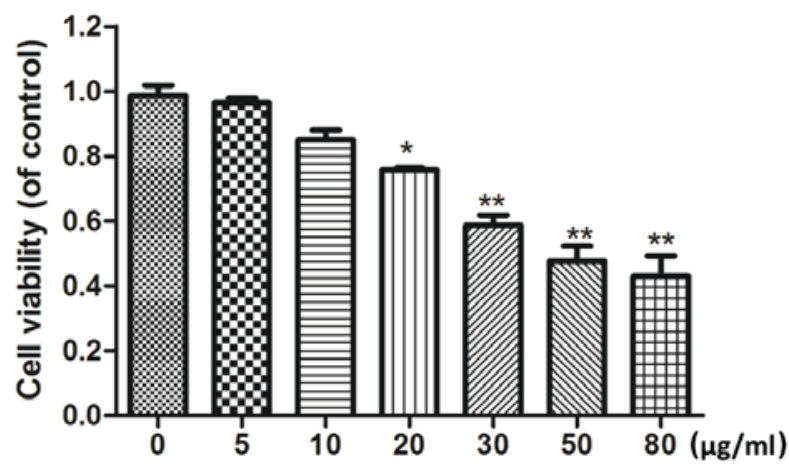

Figure 1. Detection of cell survival rate via MTT assay. Lobaplatin can inhibit the growth of lung cancer cell line NCI-H466, and when the concentration of lobaplatin is $30 \mu \mathrm{g} / \mathrm{ml}$, the cell growth can be significantly inhibited $\left({ }^{* *} \mathrm{p}<0.01,{ }^{*} \mathrm{p}<0.05\right) . \mathrm{MTT}$, methyl thiazolyltetrazolium.

$2 \mu \mathrm{g} / \mathrm{ml}$ paclitaxel and $10 \mu \mathrm{mol} / \mathrm{ml} \mathrm{LY} 294002$ were added into group LP and group LL for incubation at $37^{\circ} \mathrm{C}$ and $5 \% \mathrm{CO}_{2}$ for $24 \mathrm{~h}$. The culture solution was absorbed and the cells were washed with pre-cooled phosphate buffered saline (PBS) three times. Then the cells were digested and collected into the centrifuge tube for centrifugation for $5 \mathrm{~min}$ at $800 \times \mathrm{g}$. After that, the cells were washed with PBS again, resuspended and centrifuged under the same conditions three times. According to instructions of Annexin V-FITC apoptosis detection kit, $200 \mu 1$ staining fluid was added into each group for staining in the dark for $15 \mathrm{~min}$, then $800 \mu \mathrm{l}$ buffer was added for machine inspection, preferably within $60 \mathrm{~min}$.

Detection of cell migration capacity. The density of cells in the logarithmic growth phase was adjusted to $1 \times 10^{6}$ cells $/ \mathrm{ml}$ and spread evenly on the medium plate. Group L, group LP and group LL were set up. After the cells adhered to the wall, cell culture dish in each group was marked using the marking-off pin. After the observation area was marked, the same area was observed again after incubation for $12 \mathrm{~h}$ and photographed under the microscope. The cell migration and migration distance in each group were recorded (unit $/ \mu \mathrm{m}$ ).

Detection of cell invasion capacity. The density of cells in the logarithmic growth phase was adjusted to $5 \times 10^{5}$ cells $/ \mathrm{ml}$ and added into the Transwell chamber. Group L, group LP and group LL were set up. After the cells in each group were incubated at $37^{\circ} \mathrm{C}$ and $5 \% \mathrm{CO}_{2}$ for $24 \mathrm{~h}$, stained and fixed, the number of cells passing through the chamber was observed under the microscope and recorded.

Protein level detection. The cells in the logarithmic growth phase were spread on the 6-well plate. Group L, group LP and group LL were set up and treated for $24 \mathrm{~h}$. The protein in each group was extracted and quantified using the bicinchoninic acid protein quantification kit. The total loading quantity in each group was determined as $2 \mu \mathrm{g}$, and the loading buffer was added to prepare the loading sample. The sample was boiled under high temperature to inactivate protein, followed by $12 \%$ sodium dodecyl sulfate-polyacrylamide gel electrophoresis for $120 \mathrm{~min}$ under 


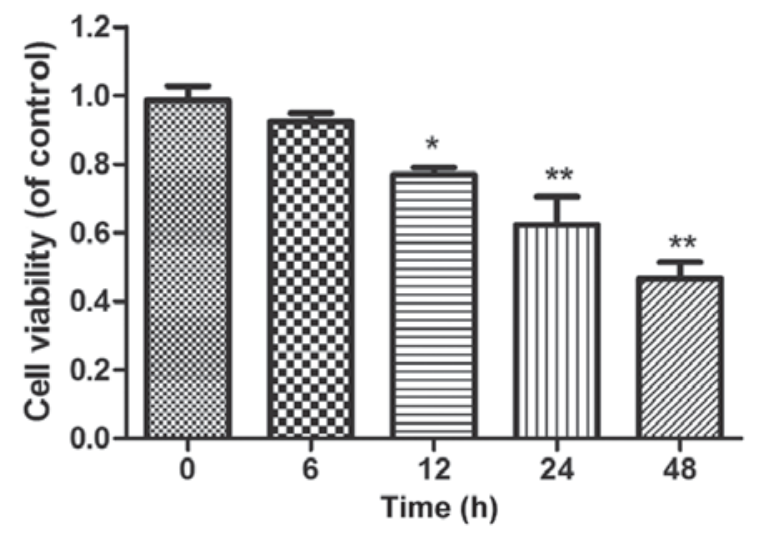

Figure 2. Detection of cell survival rate via MTT assay. Lung cancer cell line NCI-H466 was treated with $30 \mu \mathrm{g} / \mathrm{ml}$ lobaplatin for different times, and the cell growth was significantly inhibited after treatment for $24 \mathrm{~h}\left({ }^{* *} \mathrm{p}<0.01\right.$, $\left.{ }^{*} \mathrm{p}<0.05\right)$. MTT, methyl thiazolyltetrazolium.

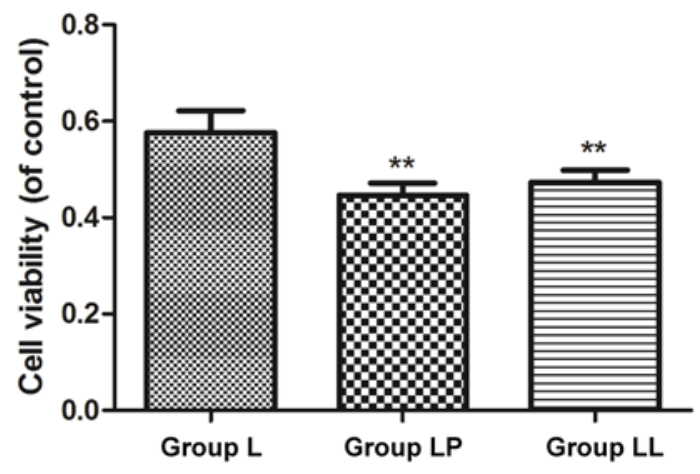

Figure 3. Detection of cell survival rate via MTT assay. The cell survival rates in group LP and group LL are significantly lower than that in group L (** $\mathrm{p}<0.01)$, and there is no statistically significant difference in the cell survival rate between group LP and group LL ( $p>0.05)$. MTT, methyl thiazolyltetrazolium; L, lobaplatin; LP, $2 \mu \mathrm{g} / \mathrm{ml}$ paclitaxel combined with lobaplatin; LL, lobaplatin combined with $10 \mu \mathrm{mol} / \mathrm{ml} \mathrm{LY} 294002$.

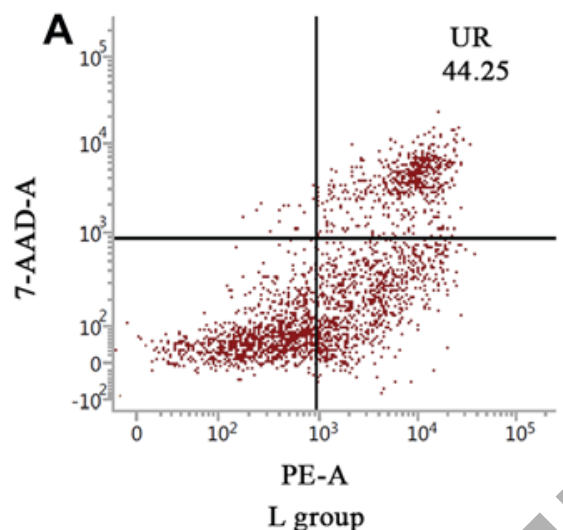

L group
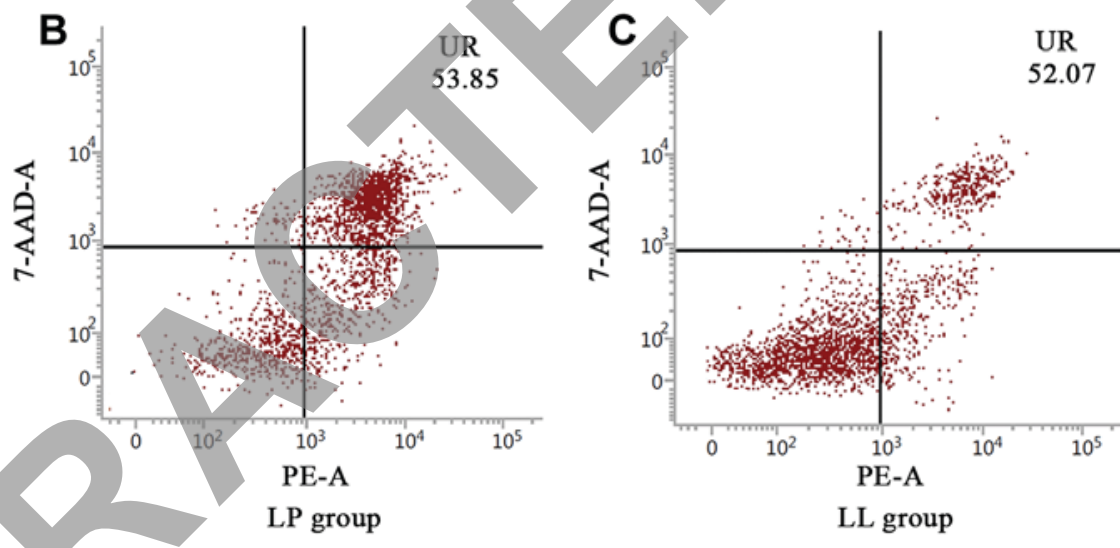

Figure 4. Detection of cell apoptosis using flow cytometry. (A) Cell apoptosis in group L; (B) cell apoptosis in group LP; (C) cell apoptosis in group LL; the apoptosis levels in group LP and group LL are higher than that in group L; there is no significant difference in the apoptosis level between group LP and group LL. L, lobaplatin; LP, $2 \mu \mathrm{g} / \mathrm{ml}$ pachitaxel combined with lobaplatin; LL, lobaplatin combined with $10 \mu \mathrm{mol} / \mathrm{ml} \mathrm{LY} 294002$.

$80 \mathrm{~V}$. Then the gel was transferred to the membrane transfer tank for preparation of membrane-transfer 'sandwich' and membrane transfer for 90 min under $100 \mathrm{~V}$. After that, the membrane was sealed using $5 \%$ skim milk powder at room temperature for $1 \mathrm{~h}$, and PI3K, p-Akt, Akt, p-GSK3 $\beta$ and GSK3 $\beta$ specific monoclonal antibodies (dilution, 1:1,000) were incubated at $4^{\circ} \mathrm{C}$ overnight, with $\beta$-actin as the internal reference. Then the membrane was washed with TBSP for $10 \mathrm{~min}$ for a total of three times. After the secondary antibody was incubated (dilution, 1:2,000) at room temperature for $2 \mathrm{~h}$, the membrane was washed again three times (10 min/time). After the tabletting time was selected according to the fluorescence intensity, the developing liquid was added onto the protein band in the dark for exposure to obtain the corresponding protein bands. After the bands were scanned, the expression level of corresponding protein in each group was detected with $\beta$-actin as the internal reference.

Statistical analysis. The data in the present study were analyzed using SPSS 19.0 software (SPSS Inc., Chicago, IL, USA). The t-test was used for intergroup comparison, while analysis of variance was used for comparison among groups.
A value of $\mathrm{p}<0.05$ was considered to indicate a statistically significant difference.

\section{Results}

Effect of lobaplatin on the growth of lung cancer cells. The growth of lung cancer cell line NCI-H446 after being treated with lobaplatin in different concentrations was detected via MTT assay. The results showed that the stability of NCI-H446 could be reduced by lobaplatin in a concentration-dependent manner. Lobaplatin $(30 \mu \mathrm{g} / \mathrm{ml})$ could significantly inhibit the growth of NCI-H446 ( $<<0.01)$, so $30 \mu \mathrm{g} / \mathrm{ml}$ lobaplatin was used for subsequent experimental study (Fig. 1). The growth of cells was detected via MTT assay after they were treated with $30 \mu \mathrm{g} / \mathrm{ml}$ lobaplatin for $6,12,24$ and $48 \mathrm{~h}$, respectively. The results revealed that the effect of $30 \mu \mathrm{g} / \mathrm{ml}$ lobaplatin on cell growth was in a time-dependent manner; the survival rate of cells could be significantly reduced after treatment for $12 \mathrm{~h}$ (Fig. 2). Group L, group LP and group LL were set up and the survival rate in each group was detected. The survival rates in group LP and group LL were significantly lower than that in group L, and the differences were statistically 
A

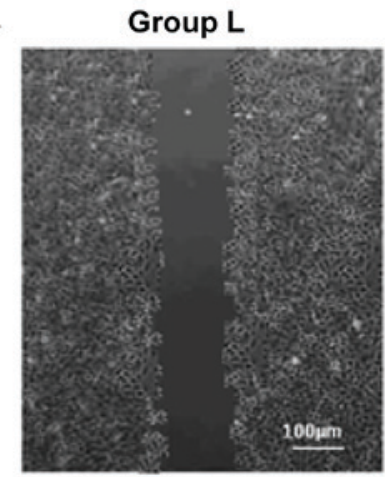

Group LP

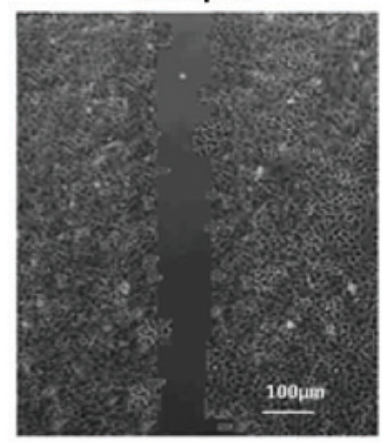

\section{Group LL}

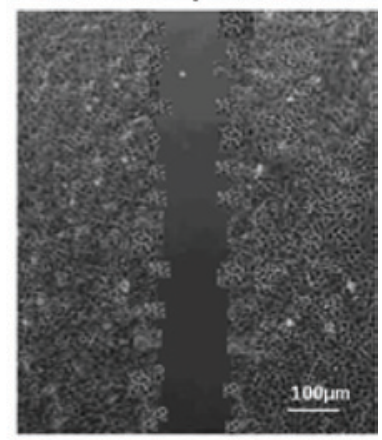

B

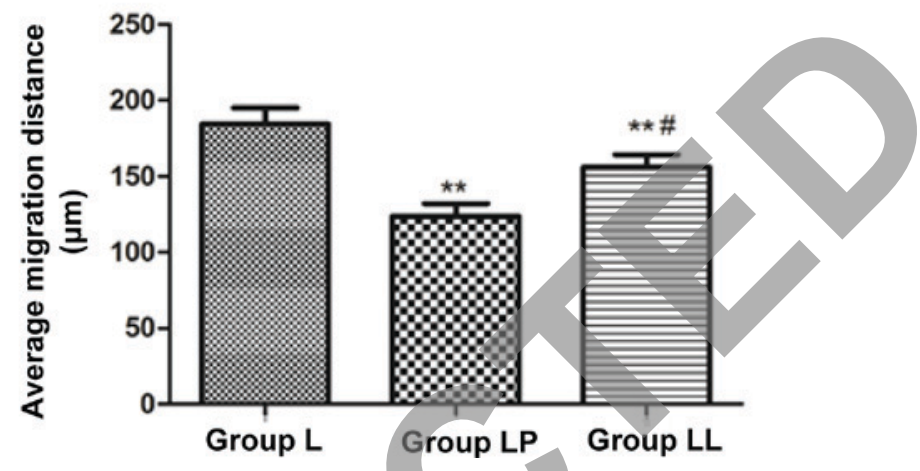

Figure 5. Detection of cell migration capability via cell wound scratch assay. (A) Cell graph under a microscope (bar, $50 \mu \mathrm{m}$ ); (B) statistical chart; the cell migration capability in group L is obviously higher than those in group LP and group LL ( $\mathrm{p}<0.01)$; the cell migration capability in group LL is higher than that in group LP $(\#$ p $<0.05)$. L, lobaplatin; LP, $2 \mu \mathrm{g} / \mathrm{ml}$ paclitaxel combined with lobaplatin; LL, lobaplatin combined with $10 \mu \mathrm{mol} / \mathrm{ml} \mathrm{LY} 294002$.

significant $(\mathrm{p}<0.01)$, and there was no statistically significant difference in the survival rate between group LP and group LL ( $>>0.05)$ (Fig. 3).

Detection of cell apoptosis level. Cell apoptosis in each group was detected using flow cytometry. The results showed that the number of cells in the 2 nd and 3 rd quadrants in group LP and group LL were significantly more than that in group L; in other words, the apoptosis levels in group LP and the group LL were higher than that in group L, and there was no significant difference in the apoptosis level between group LP and group LL (Fig. 4).

Detection of cell migration capability. The cell migration capability in each group was detected via cell wound scratch assay. The results showed that the cell migration capability in group L was obviously higher than those in group LP and group LL, and the differences were statistically significant $(\mathrm{p}<0.01)$. The cell migration capability in group LL was higher than that in group LP $(\mathrm{p}<0.05)$ (Fig. 5).

Detection of cell invasion capability. The cell invasion capability in each group was detected via Transwell assay. The results revealed that the number of invasive cells in group LP and group LL were obviously lower than that in group L $(\mathrm{p}<0.01)$, and the number of invasive cells in group LP was significantly lower than that in group LL (p<0.05) (Fig. 6).

Detection of protein expression level. In order to investigate whether PI3K/Akt signaling pathway was involved in the



Figure 6. Detection of cell invasion capability; the number of invasive cells in group LP and group LL are significantly lower than that in group L $\left({ }^{* *} \mathrm{p}<0.01\right)$, and the number of invasive cells in group LP is lower than that in group LL $(\# \mathrm{p}<0.05)$. L, lobaplatin; LP, $2 \mu \mathrm{g} / \mathrm{ml}$ paclitaxel combined with lobaplatin; LL, lobaplatin combined with $10 \mu \mathrm{mol} / \mathrm{ml} \mathrm{LY} 294002$.

effect of paclitaxel on NCI-H446, the expression levels of PI3K/Akt signaling pathway-related proteins were detected via western blotting. The results showed that compared with that in group L, the protein expression levels of PI3K in group LP and group LL were significantly decreased $(\mathrm{p}<0.01)$, and there was no statistically significant difference between group LP and group LL ( $p>0.05)$. The protein levels of $\mathrm{p}$-Akt and p-GSK3 $\beta$ in group LP and group LL were significantly lower than those in group $\mathrm{L}(\mathrm{p}<0.01)$, and there was no statistically significant difference between group LP and group LL (Fig. 7). 

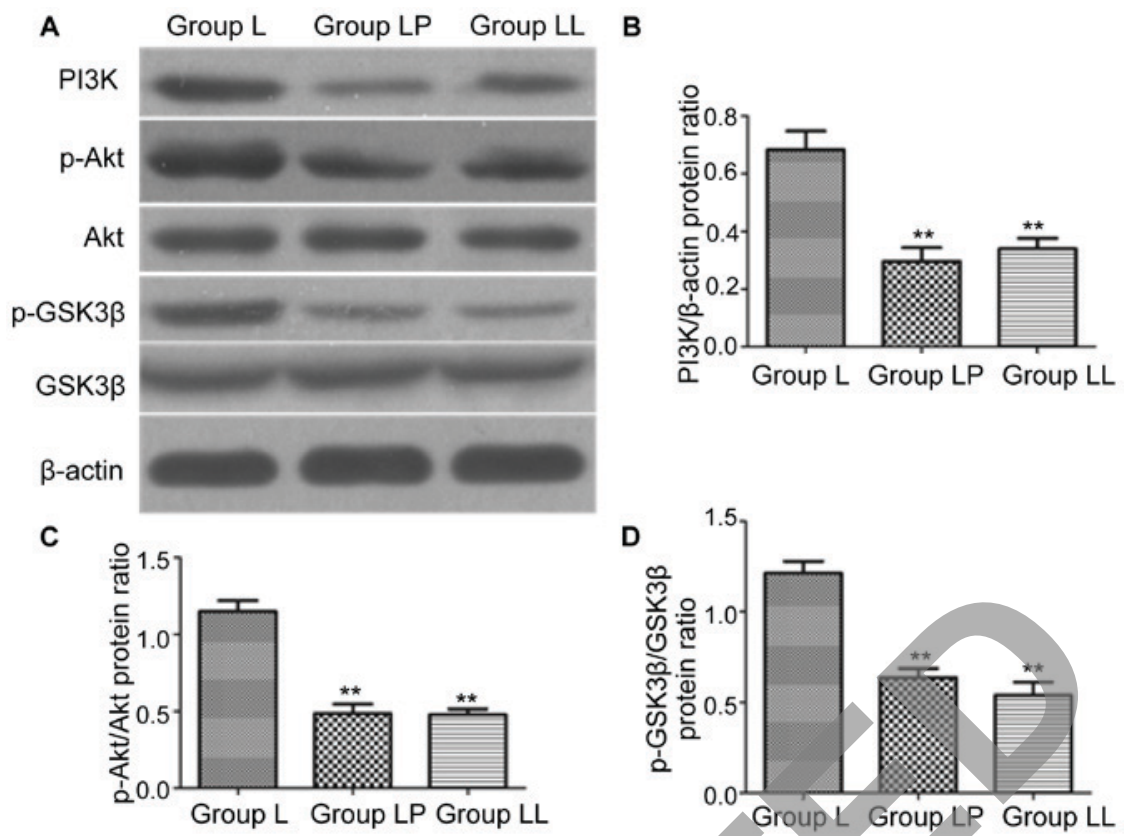

Figure 7. Detection of protein expression via western blotting; (A) western blotting diagram; (B) statistical chart of PI3K expression level; (C) statistical chart of p-Akt expression level; (D) statistical chart of p-GSK3 $\beta$ expression level; compared with those in group L, the expression levels of PI3K, p-Akt and $\mathrm{p}$-GSK3 $\beta$ in group LP and group LL are significantly decreased $\left({ }^{* *} \mathrm{p}<0.01\right)$; there are no statistically significant differences in the protein expression levels between group LP and group LL (p>0.05). L, lobaplatin; LP, $2 \mu \mathrm{g} / \mathrm{ml}$ paclitaxel combined with lobaplatin; LL, lobaplatin combined with $10 \mu \mathrm{mol} / \mathrm{ml}$ LY294002.

\section{Discussion}

Lung cancer seriously threatens human life and health, and the epidemiological survey showed that the incidence rate of lung cancer shows an increasing trend year by year, and the morbidity and mortality rates in male patients are significantly higher than those in female patients (11). Platinum drugs, as the first-line treatment drug of lung cancer, have high clinical value, characterized by the high specificity and slight side effects, but the resistance of tumor cells to platinum compounds is an important factor affecting the treatment with such compounds, so the combined administration is often clinically used to reduce the resistance of tumor cells to platinum compounds $(12,13)$. Paclitaxel is an antitumor drug extracted from the traditional Chinese medicine, bark of Taxus chinensis, which can promote the microtubule aggregation and inhibit the microtubule disaggregation, thus affecting the cell cycle and killing cells (14). The study of Zhang et al (15) showed that carboplatin combined with paclitaxel can significantly reduce the resistance of colon cancer cells to carboplatin in the treatment of colon cancer. PI3K/Akt signaling pathway exists in a variety of cells, and is involved in cell apoptosis. A number of studies have shown that this signaling pathway plays a vital role in the regulation of tumor cell apoptosis (16). The study of Cheng et al (17) found that compared with those in normal cells, the expression levels of PI3K and p-Akt in lung cancer cells are significantly increased, and the application of PI3K inhibitor can promote lung cancer cell apoptosis.

In the present study, it was found that lobaplatin could inhibit the growth of lung cancer cells. Within the range of effective concentration, the inhibitory effect on the cell growth was gradually enhanced with the increase of drug dose, as well as with the prolongation of action time; in other words, the effect of lobaplatin on lung cancer cells is concentrationand time-dependent. Lobaplatin, is a third-generation platinum antitumor drug, and one of the most widely-used antitumor drugs in clinical practice, which, with tumor cells, can form the intra-chain cross-linking between platinum and DNA bases, thus affecting the transcription and translation processes of DNA in tumor cells and killing tumor cells (18). Flow cytometry showed that the combined application of paclitaxel and lobaplatin could significantly increase apoptosis of lung cancer cells and inhibit the migration and invasion of lung cancer cells. These results indicated that paclitaxel can increase the sensitivity of lobaplatin to lung cancer cells, which can further promote apoptosis of lung cancer cells and inhibit the migration and invasion of lung cancer cells. Paclitaxel, as a kind of tubulin polymerase inhibitor, it can effectively inhibit cell mitosis and inhibit the cell proliferation, and has a certain killing effect on tumor cells, which has a synergistic effect with the antitumor effect of platinum drugs. The study of Owonikoko et al (19) reported that paclitaxel combined with carboplatin can significantly reduce the onset dose of carboplatin in the treatment of NSCLC. The effect of paclitaxel combined with lobaplatin on lung cancer cells was similar to that of lobaplatin combined with PI3K inhibitor LY294002. Besides, the detection of PI3K expression level via western blotting revealed that the expression level of PI3K in group LP was significantly lower than that in group L, but was similar to that in group LL; the expression levels of p-Akt and p-GSK3 $\beta$ in group LP and group LL were also obviously lower than those in group L, and there were no statistically significant differences in the expression levels between group LP and group LL. Paclitaxel can inhibit the phosphorylation 
of Akt and GSK3 $\beta$ through inhibiting PI3K, and regulate the $\mathrm{PI} 3 \mathrm{~K} / \mathrm{Akt}$ signaling pathway, thus regulating the proliferation of lung cancer cells and inducing lung cancer cell apoptosis. P-GSK3 $\beta$ is a necessary protein for cell survival. When PI3K is inhibited, the phosphorylation of Akt can be further inhibited, thus affecting the phosphorylation of GSK $3 \beta$, inducing cell apoptosis and inhibiting the cell migration and invasion (20).

In conclusion, paclitaxel can significantly increase the sensitivity of lobaplatin to lung cancer cell line NCI-H446, increase lung cancer cell apoptosis and decrease the onset concentration of lobaplatin through inhibiting PI3K/Akt pathway. The above results provide a theoretical basis for the clinical combination of lobaplatin and paclitaxel in the treatment of lung cancer.

\section{Competing interests}

The authors declare that they have no competing interests.

\section{References}

1. Chambers SK, Dunn J, Occhipinti S, Hughes S, Baade P, Sinclair S, Aitken J, Youl P and O'Connell DL: A systematic review of the impact of stigma and nihilism on lung cancer outcomes. BMC Cancer 12: 184, 2012.

2. Lee PN, Forey BA and Coombs KJ: Systematic review with meta-analysis of the epidemiological evidence in the 1900s relating smoking to lung cancer. BMC Cancer 12: 385, 2012.

3. Gilham C, Rake C, Burdett G, Nicholson AG, Davison L, Franchini A, Carpenter J, Hodgson J, Darnton A and Peto J: Pleural mesothelioma and lung cancer risks in relation to occupational history and asbestos lung burden. Occup Environ Med 73: 290-299, 2016.

4. Larsen JE and Minna JD: Molecular biology of lung cancer: Clinical implications. Clin Chest Med 32: 703-740, 2011.

5. Chen W, Li Z, Bai L and Lin Y: NF-kappaB in lung cancer, a carcinogenesis mediator and a prevention and therapy target. Front Biosci 1: 1172-1185, 2011.

6. Zhang B-Y, Wang Y-M, Gong H, Zhao H, Lv X-Y, Yuan GH and Han SR: Isorhamnetin flayonoid synergistically enhances the anticancer activity and apoptosis induction by cis-platin and carboplatin in non-small cell lung carcinoma (NSCLC). Int J Clin Exp Pathol 8: 25-37, 2015.

7. Ueno NT and Mamounas EP: Neoadjuvant nab-paclitaxel in the treatment of breast cancer Breast Cancer Res Treat 156: 427-440, 2016.

8. Zou H, Li L, Garcia Carcedo I, Xu ZP, Monteiro M and $\mathrm{Gu}$ W: Synergistic inhibition of colon cancer cell growth with nanoemulsion-loaded paclitaxel and PI3K/mTOR dual inhibitor BEZ235 through apoptosis. Int J Nanomed 11: 1947-1958, 2016.
9. Chen QY, Jiao DM, Wu YQ, Chen J, Wang J, Tang XL, Mou H, Hu HZ, Song J, Yan J, et al: MiR-206 inhibits HGF-induced epithelial-mesenchymal transition and angiogenesis in non-small cell lung cancer via c-Met /PI3k/Akt/mTOR pathway. Oncotarget 7: 18247-18261, 2016.

10. Mateen S, Raina K and Agarwal R: Chemopreventive and anti-cancer efficacy of silibinin against growth and progression of lung cancer. Nutr Cancer 65 (Suppl 1): 3-11, 2013.

11. Jin S, Deng Y, Hao J-W, Li Y, Liu B, Yu Y, Shi FD and Zhou QH: NK cell phenotypic modulation in lung cancer environment. PLoS One 9: e109976, 2014.

12. Samanta D, Kaufman J, Carbone DP and Datta PK: Long-term smoking mediated down-regulation of Smad3 induces resistance to carboplatin in non-small cell lung cancer. Neoplasia 14: 644-655, 2012.

13. Ma T, Fuld AD, Rigas JR, Hagey AE, Gordon GB, Dmitrovsky E and Dragnev KH: A phase I trial and in vitro studies combining ABT-751 with carboplatin in previously treated non-small cell lung cancer patients. Chemotherapy 58: 321-329, 2012.

14. Khongkow P, Gomes AR, Gong C, Man EPS, Tsang JWH, Zhao F, Monteiro LJ, Coombes RC, Medema RH, Khoo US, Lam EW: Paclitaxel targets FOXM1 to regulate KIF20A in mitotic catastrophe and breast cancer paclitaxel resistance. Oncogene 35: 990-1002, 2016.

15. Zhang Q, Si S, Schoen S, Chen J, Jin XB and Wu G: Suppression of autophagy enhances preferential toxicity of paclitaxel to folliculin-deficient renal cancer cells. J Exp Clin Cancer Res 32: 99, 2013.

16. Zhang C, Lan T, Hou J, Li J, Fang R, Yang Z, Zhang M, Liu J and Liu B: NOX4 promotes non-small cell lung cancer cell proliferation and metastasis through positive feedback regulation of PI3K/Akt signaling. Oncotarget 5: 4392-405, 2014.

17. Cheng H, Zou Y, Ross JS, Wang K, Liu X, Halmos B, Ali SM, Liu H, Verma A, Montagna C: RICTOR amplification defines a novel subset of patients with lung cancer who may benefit from treatment with $\mathrm{mTORC} 1 / 2$ inhibitors. Cancer Discov 5: 1262-1270, 2015

18. Wu Q, Qin SK, Teng FM, Chen CJ and Wang R: Lobaplatin arrests cell cycle progression in human hepatocellular carcinoma cells. J Hematol Oncol 3: 43, 2010.

19. Owonikoko TK, Ramalingam SS, Kanterewicz B, Balius TE, Belani CP and Hershberger PA: Vorinostat increases carboplatin and paclitaxel activity in non-small-cell lung cancer cells. Int J Cancer 126: 743-755, 2010.

20. Tang X, Zheng D, Hu P, Zeng Z, Li M, Tucker L, Monahan R, Resnick MB, Liu M and Ramratnam B: Glycogen synthase kinase 3 beta inhibits microRNA-183-96-182 cluster via the $\beta$-Catenin/TCF/LEF 1 pathway in gastric cancer cells. Nucleic Acids Res 42: 2988-98, 2014.

c) (i) $\Theta$ This work is licensed under a Creative Commons Attribution-NonCommercial-NoDerivatives $\quad 4.0$ International (CC BY-NC-ND 4.0) License. 